\title{
The influence of implementation school operational assistance policy towards students Achievement
}

\author{
Sopyan, Rifdan, Muhammad Guntur \\ Public Administration Science, Universitas Negeri Makassar \\ Email: fhyan.mf_stindo@yahoo.com
}

(Received: May-2020; Reviewed: July-2020; Accepted: July-2020;

Avalaible Online: July-2020; Published: August-2020)

This is an open access article distributed under the Creative Commons Attribution License
CC-BY-NC-4.0 (C2020 by author (https://creativecommons.org/licenses/by-nc/4.0/)

\begin{abstract}
The government issued a policy of BOS (School Operational Assistance) aims to maximize the performance of schools to meet all school needs that can support student learning achievement which ultimately results in good and quality educational goals. The purpose of this study was 1) to find out the implementation of the School Operational Assistance (BOS) policy at SMK Negeri 5 Pangkep in Pangkejene and Kepulauan Regency, 2) to determine the level of student achievement in SMK 5 Pangkep in Pangkejene and Kepulauan Regency, 3) to determine the effect of the policy School Operational Assistance (BOS) on the level of student achievement in SMK 5 Pangkep in Pangkejene and Kepulauan Regency. This research uses a quantitative approach, with a population of 305 people and a sample of 62 respondents. Data collection techniques through observation, angekt, interviews and documentation. Data analysis techniques in this study used descriptive analysis and inferential statistical analysis. The results showed that 1) The implementation of BOS policy of the four indicators ranging from communication, resources, disposition, and bureaucratic structure as a whole was considered to be going well which reached a percentage of 77.33 percent, 2) Student achievement in SMK Negeri 5 Pangkep from cognitive, psychomotor, and affective indicators which overall of the three indicators reached report card which is 4 or 82.17 percent considered good. 3) The implementation of BOS policy has a moderate and positive influence on student achievement with an R square (r2) score of 42.10 percent. The influence of the management of BOS funds on student achievement in SMK 5 Pangkep has a positive impact because of the availability of facilities needed by students even though it is not adequate or complete as a whole, but its management has been maximally used in improving student achievement. In addition, with the BOS funds the costs incurred by parents of students are also aided so that there is encouragement so that their children can increase education at school and develop the talents and interests of the students.
\end{abstract}

Keywords: Policy Implementation; School Operational Assistance; Learning Achievement 


\section{INTRODUCTION}

In principle, the School Operational Assistance (BOS) policy program was initiated as an effort to improve community access, especially students from poor or underprivileged families to quality education in order to complete compulsory basic education and secondary education (Syam et al., 2018). Regarding the issue of education costs, the issuance of Government Regulation of the Republic of Indonesia number 66 year 2010 concerning Amendment to Government Regulation of the Republic of Indonesia number 17 year 2010 concerning Management and Implementation of Education.

Based on the government regulations above related to education cost assistance, so the government made a policy of granting School Operational Assistance (BOS) funds as stipulated in the Republic of Indonesia's Minister of Education and Culture Regulation No. 1 of 2018 concerning Technical Guidelines for School Operational Assistance (BOS) which is explained Article 1 Paragraph (3) which reads "School Operational Assistance, hereinafter referred to as BOS, is a Central Government program to provide funding for non-personnel operating costs for primary and secondary education units. Once the importance of education for the progress of the nation is expected that the granting of School Operational Assistance (BOS) funds can be carried out as fairly as possible and precisely in its target, namely students who are entitled to School Operational Assistance (BOS), namely students who are less able or unable (Handoko et al., 2020; Setyoko et al., 2016; Suharyo et al., 2006; Sulistyaningrum, 2016). Management of education funding will directly affect the quality of schools, especially related to infrastructure and learning resources. Many schools are unable to carry out teaching and learning activities optimally, only because of financial problems, both to pay teachers and to procure learning infrastructure. In addition to that student learning achievement is also very influenced by the ability of a teacher as a teacher as well as an educator (Suknaisith et al., 2014; Usman, 2017).

Therefore, in order to realize the goals of education by achieving good learning achievements, the BOS program is expected to be able to meet all school operational costs and provide affordable educational services for poor students and improve student learning achievement in schools. An important factor for achieving maximum success in using BOS funds is how the BOS funds are managed by the school. A good management system will help to achieve the objectives of the BOS funding program effectively and efficiently which of course can improve the quality of education as expected. As this was stated by Mulyasa (2004: 194) said that with the existence of the BOS funding program, schools were required to be able to plan, implement and evaluate and account for the management of these education costs transparently to the community and government .

Apart from that, it can be understood that this School Operational Assistance policy is a policy from the center to the regions, it means the policy has a Top down model, suggesting approaches in implementing public policy can be grouped into three models namely "Top-down, bottom-up, and hybrid models". One implementation model that uses aapproach top-down is the implementation model of Van Meter and Van Horn, in addition there is also apolicy implementation top-down model of G. Edwards III Model as follows: According to Edwards III in Subarsono (2005: 114) satated that the implementation policy is influenced by four variables, namely: "(1) communication, (2) resources, (3) disposition, and (4) bureaucratic structure" (Stein et al., 1984).

With the presence of BOS funds, which is a government program in overcoming education problems, it is expected to be able to change these assumptions even though the government is currently providing a School Operational Assistance budget. But in its application, there are still many schools, especially in high schools who have not fully felt the 
impact of these funds. The provision of school facilities and infrastructure, as well as the provision of inadequate textbooks, is still a true illustration of where the BOS funds flow.

Observing the implementation of the BOS fund policy which is also considered so far has not been able to suppress misuse in its management. Misappropriation of BOS funds in schools seems to have become a phenomenon. One of the reason is low transparency, accountability, and community participation in its management. By channeling School Operational Assistance funds, schools are required to waive student tuition fees from operational fees. In addition to reducing the burden on parents, BOS is directed towards increasing student learning achievement, which of course leads to quality educational goals. BOS assistance is expected to be able to facilitate people who are unable to continue schooling. With the existence of BOS school facilities should also be a concern, because education not only requires theory but also requires practice to support the skills possessed and develop the potential that exists in students.

\section{METHOD}

Type of this research is quantitative research with approach or a quantitative descriptive design. This study examined two variables: BOS policy as an independent variable (independent) and students learning achievement as dependent variable (dependent). The population in this study were students in grade I and II at SMK Negeri 5 Pangkep totaling 305 people and determining the sample using accidental techniques by taking $20 \%$ of 305 people, so the sample of this study was 62 respondents. Variable measurements are carried out using the ordinal scale and the Likert scale. Data collection techniques are observation, questionnaire, interview and documentation. Data analysis techniques used descriptive statistics and inferential statistical analysis techniques (Creswell \& Creswell, 2017).

\section{RESULT AND DISCUSSION}

\section{Implementation of School Operational Assistance Policy (BOS)}

To find out the overall picture of the BOS policy implementation variable at SMK Negeri 5 Pangkep, it can be seen in the descriptive statistical analysis that includes indicators of Communication (X1), resources (X2), dispoisisi (X3), and bureaucratic structure (X4), can be seen in the table below.

Table 1

Level of Achievement Score Variable Implementation of School Operational Assistance Policy (BOS)

\begin{tabular}{|c|c|c|c|c|c|c|}
\hline \multirow{2}{*}{$\begin{array}{l}\text { Variabel / } \\
\text { Indicator }\end{array}$} & \multicolumn{4}{|c|}{ Actual Range } & \multirow{2}{*}{$\%$} & \multirow{2}{*}{ Ket. } \\
\hline & Min & Max & Med & Average & & \\
\hline $\begin{array}{c}\text { Policy } \\
\text { Implementation } \\
\text { BOS }\end{array}$ & 15 & 48 & 38 & 37,12 & 77,33 & Good \\
\hline X.1 & 4 & 9 & 7 & 6,42 & 71,33 & Good \\
\hline $\mathrm{X} .2$ & 4 & 9 & 7 & 6,24 & 69,33 & Good enough \\
\hline X.3 & 4 & 7 & 6 & 5,13 & 73,28 & Good enough \\
\hline X.4 & 3 & 7 & 6 & 5,51 & 78,71 & Good \\
\hline
\end{tabular}

Source: Results of Questionnaire Data No. 1-15 
In general, from the processed descriptive statistical data of BOS policy implementation variables, it appears that the comparison of mean and median values, both the variables and all indicators show that the mean values are approximately equal to the median values, so that it can be said that BOS policy implementation is in the range of values between $0.60-0.79$ are categorized as good, this is in accordance with the measurement of variables that range from 76 percent to 100 percent is categorized as good.

With the role of the principal being so important in managing the allocation of funding for school operations. In this case also the results of an interview with the manager of Pangkep District education office BOS fund (on May 14, 2019) said that: "We from the Education Office are in accordance with operational operational standards, when distribution of aid funds, the school will sometimes deliver in writing for all the needs and use of operational assistance funds".

The implementation of the School Operational Fund (BOS) policy uses the Edward III Implementation Model which measures policy implementation with 4 factors namely communication, resources, disposition and bureaucratic structure. Seeing the results of research in percentage where the communication dimension gained 71.33 percent which means good, where the form of transmission of communication in this BOS fund policy is by way of schools involving some of the teachers involved in managing boss funds to participate in training activities related to the BOS Fund Management Guidance which aims so that all information about BOS funds can be known with certainty through these activities. Meanwhile, so that the BOS fund policy can also be known and understood by students, the BOS fund management team namely the school principal always conveys this during the ceremony on Monday. Besides that, the BOS fund management team also posted information on the school wall regarding the allocation of BOS funds.

In the implementation of BOS fund policies so that the delivery of information on the implementation can be received clearly and can be understood, the delivery of information by the BOS fund manager is also carried out directly. This direct delivery was assessed the correct way by conducting meetings and a dialogue with the teacher and also the parents of students who had been done so far. The communication carried out by the BOS fund manager is done transparently by conveying the amount of the BOS fund budget and also showing the teachers and parents of the components to be financed.

Human resources (staff) referred to in the implementation of BOS funding policies are principals who are assisted by several teachers starting from the readiness in terms of qualifications, competencies and also ready in terms of understanding and paradigm (mindset) for the management of BOS funds. While the research results obtained, the attitude of implementation in the implementation of the policy of Operational Assistance Funds of SMK Negeri 5 Pangkep always supports and is ready to implement BOS fund assistance policies to build education at SMK Negeri 5 Pangkep. Furthermore, it is seen from the aspect of bureaucratic structure that is considered to be good, this is indicated by the SOP of the implementation of BOS funds which will be managed separately by SMK Negeri 5 Pangkep. The SOP also regulates the allocation of each BOS fund budget post and the BOS fund manager in SMK 5 Pangkep has also managed BOS funds that have been stipulated in the SOP as stipulated in the technical manual for implementing BOS fund management.

\section{Students Achievement}

learning achievement variable in SMK 5 Pangkep can be seen in the indicators consisting of; cognitive (Y1), psychomotor (Y2), and Affective, (Y3). The measurement of 62 student 
report cards is carried out using a Likert scale with a range of grades 1-4. The measurement results for each indicator can be seen in the table below.

Table 2

Level of Students Achievement Score

\begin{tabular}{|c|c|c|c|c|c|c|}
\hline \multirow{2}{*}{$\begin{array}{l}\text { Variable/ } \\
\text { Indicator }\end{array}$} & \multicolumn{4}{|c|}{ Actual Range } & \multirow{2}{*}{$\%$} & \multirow{2}{*}{ Ket. } \\
\hline & Min & Max & Med & Average & & \\
\hline Achievement & 62 & 77 & 64 & 63,19 & 82,17 & Good \\
\hline Y.1 & 62 & 77 & 64 & 63,90 & 82,11 & Good \\
\hline Y.2 & 62 & 77 & 64 & 63,54 & 82,24 & $\begin{array}{c}\text { Good } \\
\text { Enough }\end{array}$ \\
\hline Y.3 & 62 & Constant & Constant & Constant & $\begin{array}{c}\text { Constan } \\
\mathrm{t}\end{array}$ & Constant \\
\hline
\end{tabular}

Source : Results of Data Processing Student Report Score 1-62 people

From table 2 shows the average value of student achievement in SMK Negeri 5 Pangkep grade I and II reached a percentage of 82.11 percent for cognitive values, for psychomotor scores have an average the average percentage is 82.24 percent, and for the affective category the value is constant. So that overall of the three aspects above, it is known that the level of student achievement in SMK Negeri 5 Pangkep reaches an average value of 82.17 percent, which means the level of student achievement in SMK 5 Pangkep is already good, this is in accordance with the measurement of the variable range of 76 percent - 100 percent is good. The results of student achievement levels from 2017 to 2019 can be seen in the graphic image below.

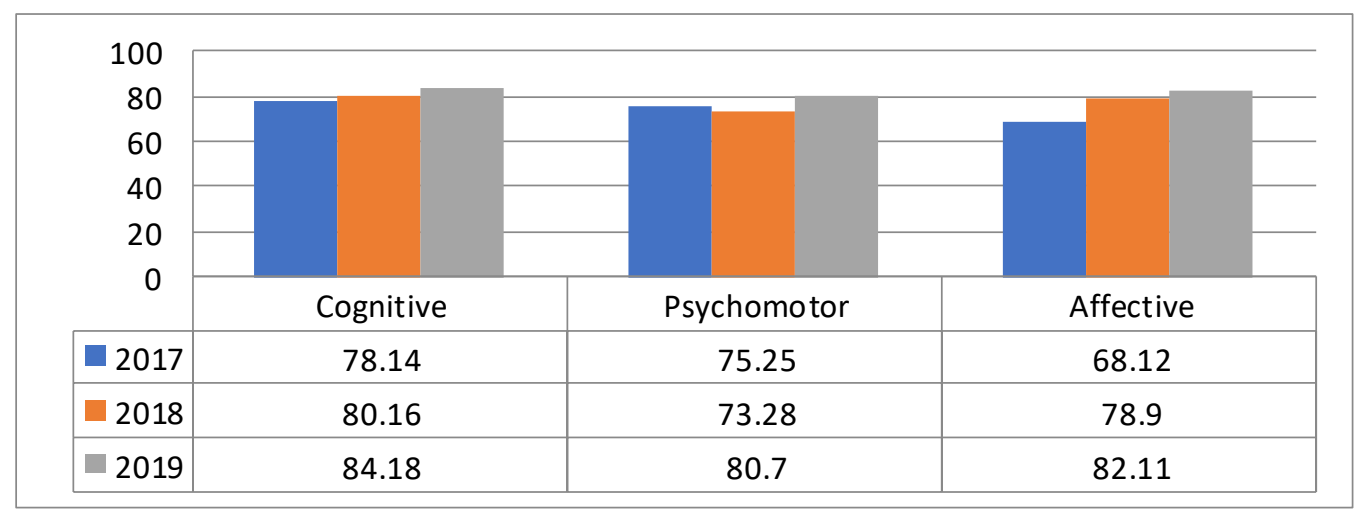

Data source : Administration of State Vocational School 5 Pangkep, 2019

\section{Ficture 1}

\section{Levels of Students Achievement}

Based on the data above, shows that the level of student learning achievement of State Vocational School 5 Pangkep has been increasing year by year, where this can be seen from the percentage level obtained from the assessment for each cognitive, psychomotor and affective aspects as a whole have increased in 2019 which reached an average of 81.14 percent. This means that the percentage level shows that the students of SMK 5 Pangkep Regency have good learning motivation and can actualize all the subject matter they receive from the teachers by 
behaving well so that a learning achievement is achieved by the students of SMK Negeri 5 Pangkep.

The research results found by researchers factually can be revealed that cognitive achievement and student responses that show good performance towards the implementation of learning carried out at SMK Negeri 5 Pangkep. From the results of the initial and final test students can be reported that student achievement has increased in 2019 from previous years. This means that students' grades have increased after learning using a number of teaching strategy approaches conducted by teachers of SMK Negeri 5 Pangkep. Students are very happy with the integrated learning approach such as lecture, discussion and accompanied by the display of images through the power point of the teacher's material.

To get an achievement is not as easy as imagined, because it requires struggle and sacrifice with various challenges that must be faced. Assessment of student learning outcomes to find out how far students have achieved learning goals is what is referred to as learning achievement. As said by Amirullah et al., (2018) that the learning process experienced by students produces changes in the fields of knowledge and understanding, in the areas of values, attitudes and skills. The existence of these changes can be seen in the learning achievements generated by students of questions, problems or assignments given by the teacher. Through learning achievements students can find out the progress that has been achieved in learning (Aljaber, 2018; Gillborn et al., 2017; Sletten, 2017). One of the efforts used to realize educational goals is to increase student learning achievement.

Learning achievement is the result of what is learned by learning so a person can add to his knowledge (cognitive), behavior / values (affective), and psychomotor. Cognitive knowledge is one of the important factors and must be considered by anyone, especially teachers in the teaching and learning process, as revealed by cognitive theory cited by Muhibin cognitive psychology is the most important part of cognitive science that has made a very significant contribution in the development of learning psychology. The results of research to students on subjects can be said to be good (74-88), which are related to cognitive include learning achievement and the value obtained has reached KKM, understand and be able to apply the existing lessons in school.

As the importance of cognitive assessment for student achievement, affective assessment (attitude / behavior) is no less important, the observations made by researchers at the 5 Pangkep Vocational School in January to May 2019 can be explained that, after students get lessons in class, then the material is implemented by students into everyday attitudes towards what has been given by the teacher, by behaving politely, honestly, disciplined and passionately in learning. The results of research on the psychomotor domain can be said to be good because students of SMK Negeri 5 Pangkep have mastery of well-taught material and the seriousness of learning. From the results of observations made by researchers on student achievement in learning in the classroom it can be found that students are able to understand well from each subject and answer test questions during semester exams with high marks.

\section{The Influence of BOS Policy Implementation on Student Achievement}

Results of the calculation of simple linear regression analysis to test the presence or absence of the influence of BOS policy on student achievement. From the results of simple linear regression analysis, the data of this study are obtained in the table below: 
Table 3

Anova table of policy implementation on student achievement ANOVA ${ }^{\mathrm{a}}$

\begin{tabular}{|ll|r|r|r|r|r|}
\hline Model & Sum of Squares & Df & Mean Square & F & \multicolumn{1}{c|}{ Sig. } \\
\hline 1 & Regression & .014 & 1 & .014 & .286 & $.001^{\mathrm{b}}$ \\
& Residual & 1678.442 & 61 & 19.073 & & \\
& Total & 1678.456 & 62 & & & \\
\hline
\end{tabular}

a. Dependent Variable: Y

b. Predictors: (Constant), $\mathrm{X}$

From the ANOVA results obtained a Fcount of 28.6> Ftable of 23.2. Then $\mathrm{H} 0$ is rejected and $\mathrm{H} 1$ is accepted, which means that there is an influence of school operational assistance policy on student achievement in SMK 5 Pangkep Regency. In addition, the calculation results above show a significance number of $0.01<0.05$ then $\mathrm{H} 0$ is rejected and $\mathrm{H} 1$ is accepted, which means that simultaneously (together) the influence of school operational assistance policies on student achievement is significant.

Furthermore, looking at the correlation test results product moment to determine whether there is and how much influence the policy of school operational assistance (BOS) on student achievement in SMK 5 Pangkep Regency can be seen in the calculations in the summary model and the coefficient of determination, specifically the Rnumber square, as shown in the table below.

Table 4

Model Summary

\begin{tabular}{|l|r|r|r|r|}
\hline Model & \multicolumn{1}{|c|}{$\mathrm{R}$} & \multicolumn{1}{c|}{ R Square } & Adjusted R Square & \multicolumn{2}{|c|}{ Std. Error of the } \\
\hline 1 & $.446^{\mathrm{a}}$ & .421 & .383 & 2.56 \\
\hline
\end{tabular}

a. Predictors: (Constant), Implementasi Kebijakan BOS

b. Dependent Variable: Prestasi Belajar Siswa

The amount of $\mathrm{R}$ square $\left(\mathrm{r}^{2}\right)$ in table 14 is 0.421 , meaning that the contribution of the implementation of BOS policy to student learning achievement is 42.10 percent. This means there are still other factors that contribute as much as 57.90 percent to student learning achievement. The value of the influence of the implementation of BOS policy on student achievement in SMK 5 Pangkep Regency based on guidelines to provide an interpretation of the correlation coefficient or $r$ value proposed by Sugiyono (2016: 214) shows the implementation of BOS policy has a moderate effect on student achievement with a value of $r$ of 42.10 percent.

Based on the results of the study showed that the influence of the BOS policy on student achievement in SMK 5 Pangkep which showed a moderate influence, meaning that to improve student achievement there are still other factors other than the BOS policy (Suheni et al., 2018). The BOS Fund (School Operational Assistance) Program in improving student learning achievement is a mission of the school where one of its missions is to make maximum use of existing facilities and infrastructure for effective learning activities. In managing BOS Funds at the 5 Pangkep State Vocational School, from the results of our interviews with the school principal, all the programs that are activities in the school all aim at improving student achievement. The availability of a variety of tiger package books, learning media and adequate extracurricular activities facilities so that it has an attraction for students to learn and develop students' talents and interests. this can be seen from the increase in student achievement both 
subject and extracurricular grades and seen from the number of awards obtained in each race along with an increase in the number of new students and graduation achievements.

The interview we did with one of the teachers said that there were many things that were done as an effort to improve student achievement in SMK 5 Pangkep. These efforts are effective steps in the learning process. This is a response to all parties in the Vocational School 5 Pangkep on the condition of the world of education that experienced a deterioration in quality. Both teachers and parents continue to strive for children to get the best learning process, so various efforts are made one of them is to follow the tutoring and try out.

Efforts to improve student learning achievement by teachers in the form of additional tutoring in learning are generally emphasized on material not yet mastered by students. This teacher knows with certainty the level of student ability. With this knowledge, students get stabilization according to their needs.

The obstacle experienced in administering the BOS Fund program is the slow disbursement of the BOS funds or not in accordance with the disbursement time, so that the school operational and student operational funding is also late. In terms of the number of students each year increasing and the availability of textbooks, funding student activities, financing teaching and learning processes, procurement of tools and learning media, and sports facilities so that schools can compete with other schools to ensure an increase in the quality of education and achievement for schools and students.

With the operational assistance of the school (BOS), it really helps ease the burden on the community because there is no more moral burden on parents, especially to students who have poor backgrounds. even all student needs related to learning are all free and teaching and learning facilities have been provided by the school. The efforts made by the government through the BOS Fund program in terms of improving student achievement are very appropriate. Because implementing the nine-year compulsory education program, with the BOS Funds \& free education the government hopes that there will be no more citizens dropping out of school because there are no fees so students have a high interest in learning at school and as a result, students can get achievement (Suheni et al., 2018; Wasono et al., 2019).

So, from the explanation above, it can be understood that the implementation of the BOS Fund program is one of the government's efforts to provide assistance to students in order to be able to continue and get proper education without having to incur large costs. Especially in SMK 5 Pangkep, the management and use of BOS funds can make students who carry out education and learning processes have a high interest in learning to improve learning achievement. Because effective and efficient learning processes are supported by adequate school facilities and infrastructure. It is also known that the existence of the BOS funding program from the government is very helpful and provides great benefits to education in Indonesia and the schools are free to plan education and learning programs in schools in accordance with the instructions for using and managing school operational assistance (BOS). 


\section{CONCLUSION}

Based on the results of the study it can be concluded that: 1) Implementation of BOS fund policies (School Operational Assistance) at SMK 5 Pangkep has been realized well with the results of a percentage value of $77.33 \%, 2$ ) The level of student achievement in SMK 5 Pangkep is rated it is good that reaches a percentage value of $82.17 \%, 3$ ). The BOS policy on student achievement in SMK 5 Pangkep has a moderate or significant influence of $42.10 \%$. From the results of this study there are also a number of recommended recommendations, namely; 1) The school principal prepares the BOS fund budget design to all teachers with more transparency so that teachers better understand matters that are pleased with the implementation of the BOS program in accordance with the operational guidelines, 2) Schools continue to always coordinate with the regional government (Province) in terms of the mechanism for channeling BOS funds to avoid delays in channeling BOS funds, 3) Schools and regional governments work together to realize administrative officers as treasurers of BOS funds in schools through training or financial support, 4) Central and local governments need to review the government the size of the BOS funding unit that is associated with demands for quality improvement and the overall economic situation with the hope of improving learning and the quality of education will increase, 5) It is expected that future researchers, to be able to develop the results of this study using other approaches or perspectives in seeing the performance of employees in government agencies.

\section{REFERENCES}

Aljaber, A. (2018). E-learning policy in Saudi Arabia: Challenges and successes. Research in Comparative and International Education, 13(1), 176-194.

Amirullah, A. H., Iksan, Z. H., Suarman, H., Hikmah, N., Ibrahim, N. H. B., Iksan, Z. B. H., Islami, N., Chairilsyah, D., Kurnia, R., \& Junita, D. (2018). Lesson Study: An approach to increase the competency of out-of-field mathematics teacher in building the students conceptual understanding in learning mathematics. Journal of Educational Sciences, 2(2), $1-13$.

Creswell, J. W., \& Creswell, J. D. (2017). Research design: Qualitative, quantitative, and mixed methods approaches. Sage publications.

Gillborn, D., Demack, S., Rollock, N., \& Warmington, P. (2017). Moving the goalposts: Education policy and 25 years of the Black/White achievement gap. British Educational Research Journal, 43(5), 848-874.

Handoko, H., Rustiadi, T., \& Mukaromah, S. B. (2020). Implementation of the Use of School Operational Assistance (BOS) Funds in Fulfilling Middle School Sports Infrastructure Facilities in Ngadirejo District. Journal of Physical Education and Sports, 9(2), 108-113.

Setyoko, A., Tunas, B., \& Sunaryo, W. (2016). Evaluation of school operational assistance by using CIPP model in Indonesia private Islamic elementary school. International Journal of Managerial Studies and Research, 4(3), 44-49.

Sletten, S. R. (2017). Investigating flipped learning: Student self-regulated learning, perceptions, and achievement in an introductory biology course. Journal of Science Education and Technology, 26(3), 347-358.

Stein, R. M., Eyestone, R., \& Edwards III, G. (1984). Policy Implementation in a Federal System,'. Policy Formulation and Implementation.

Suharyo, W. I., Sumarto, S., Usman, S., Toyamah, N., Sulaksono, B., Budiyati, S., Widyanti, W. D., Rosfadhila, M., Sodo, R. J., \& Bazzi, S. (2006). A Rapid Appraisal of The PKPSBBM Education Sector: School Operational Assistance (BOS). East Asian Bureau of 
Economic Research.

Suheni, S., Jaenam, J., Suarja, S., \& Zulkifli, Z. (2018). The Performance of School Leader Elements as Impact of the Implementation of Regional School Operational Assistance (Bosda) Policy. International Conference on Teacher Training and Education 2018 (ICTTE 2018).

Suknaisith, A., Wongwanich, S., \& Piromsombat, C. (2014). Development of Teacher Performance in Educational Measurements and Evaluation through Self-monitoring Strategies. Procedia - Social and Behavioral Sciences, 116, 1683-1688. https://doi.org/https://doi.org/10.1016/j.sbspro.2014.01.456

Sulistyaningrum, E. (2016). Impact Evaluation of the School Operational Assistance Program (Bos) Using the Matching Method. Journal of Indonesian Economy and Business, 31(1), 33-662.

Syam, A., Hasbiah, S., Yunus, M., \& Akib, H. (2018). Determinants of entrepreneurship motivation for students at educational institution and education personnel in Indonesia. Journal of Entrepreneurship Education, 21(2).

Usman, A. (2017). Influence of Motivation on the Performance of Government Employees. 2nd International Conference on Education, Science, and Technology (ICEST 2017).

Wasono, R., Karim, A., \& Darsyah, M. Y. (2019). Budgeting school operational assistance in Central Java using three spatial process modelling. Journal of Physics: Conference Series, $1217(1), 12112$. 